\title{
Analisis Karakteristik Pasien Trauma Mata di RSUP Dr. M. Djamil Padang Tahun 2016
}

\author{
Eldisha Nofityari ${ }^{1}$, Fitratul $l l a h i^{2}$, Novita Ariani $^{3}$
}

\begin{abstract}
Abstrak
Trauma mata termasuk salah satu kasus kegawatdaruratan bagian mata, jika tidak segera ditatalaksana dapat menyebabkan kebutaan yang menimbulkan kerugian fisik, psikologi, dan sosioekonomi. Tujuan penelitian ini adalah menentukan hubungan jenis kelamin, usia, pekerjaan, lateralisasi, dan visus terhadap jenis trauma mata pada pasien di IGD dan Poliklinik Mata RSUP Dr M Djamil Padang. Jenis penelitian ini adalah analitik dengan desain crosssectional study. Penelitian ini dilakukan di bagian rekam medis RSUP Dr.M.Djamil Padang mulai bulan Oktober 2017 sampai Februari 2018. Populasi penelitian ini adalah seluruh pasien trauma mata yang datang ke IGD dan Poliklinik Mata RSUP Dr.M.Djamil Padang tahun 2016 dengan sampel minimal sebanyak 51 orang. Analisis statistik yang digunakan adalah Uji Korelasi Lambda. Hasil penelitian ini menunjukkan bahwa sebagian besar trauma mata terjadi pada laki-laki $(77,6 \%)$, usia $22-45$ tahun $(27,6 \%)$, profesi pelajar $(44,7 \%)$, unilateral $(94,7 \%)$ dan menimbulkan kebutaan $(64,47 \%)$. Diagnosis yang paling sering ditemukan ruptur kornea $(21,05 \%)$ dan jenis trauma tersering adalah trauma tajam $(60,5 \%)$. Terdapat hubungan antara usia, pekerjaan, lateralisasi dan visus pasien trauma mata dengan jenis trauma mata, tetapi tidak terdapat hubungan antara jenis kelamin pasien trauma mata dengan jenis trauma mata.
\end{abstract}

Kata kunci: trauma mata, jenis kelamin, usia, pekerjaan, lateralisasi, visus

\section{Abstract}

Eye injuries is one of the emergency cases in eye department, in which if not treated immediately, will have a high risk of developing eye blindness with negative physical, psychological, and socioeconomic impacts. The objective of this study was to determine the relationship between gender, age, occupation, lateralization, and vision on the types of eye injuries in emergency patients at the emergency and Ophthalmology polyclinic department in Dr.M.Djamil Hospital Padang. This type of research was analytic with cross-sectional study design. This study was conducted in the medical record Dr M Djamil Hospital Padang from October 2017 until February 2018. Population of this study was all the patients with eye injuries reported at the emergency and the Ophthalmology polyclinic department in 2016 with the minimal amount of samples were 51 patients. The statistical analysis was Lambda correlation measure. The results of this study indicated that most eye trauma occurs in males (77,6\%), ages $22-45$ years (27,6\%), student professions $(44,7 \%)$, unilateral $(94,7 \%)$ and cause blindness $(64,47 \%)$. The most commonly found diagnosis is corneal rupture $(21,05 \%)$ and the type of trauma is sharp trauma (60,5\%). There are significant relationship between the age, occupations, lateralization, and vision of the patients on the types of eye injuries, but there is no significant relationship between gender of the patients with the types of injuries.

Keywords: eye injuries, gender, age, occupation, lateralization, vision

\footnotetext{
Affiliasi penulis: 1. Prodi Kedokteran Fakultas Kedokteran Universitas Andalas Padang (FK Unand) 2. Bagian IImu Kesehatan Mata FK Unand/RSUP Dr. M. Djamil Padang, 3. Bagian Radiologi FK Unand/RSUP Dr. M. Djamil Padang

Korespondensi: Eldisha Nofityari, Email: eldishan@gmail.com, Telp: 082310596000
}

\section{PENDAHULUAN}

Mata mempunyai sistem pelindung yang baik, seperti rongga orbita, jaringan lemak retrobulbar, palpebra serta reflek mengedip. Mata masih sering mendapat trauma dari lingkungan luar. Trauma mata adalah perlukaan/cedera mata yang dapat terjadi dalam 
bentuk trauma tumpul, trauma tajam, trauma kimia, trauma termis dan trauma radiasi. Trauma mengakibatkan kerusakan pada jaringan mata anterior sampai posterior. Trauma mata merupakan kasus kegawatdaruratan, jika tidak segera ditatalaksana dapat menyebabkan penurunan visus (low vision) hingga kebutaan.Seseorang dinyatakan mengalami penurunan visus jika tajam penglihatan berkisar antara 6/18 sampai $3 / 60$ dan buta jika tajam penglihatan kurang dari $3 / 60{ }^{1}$

Trauma mata merupakan penyebab kebutaan tersering di dunia setelah katarak, glaukoma, degenerasi makula, retinopati diabetik dan trakoma. Di Indonesia, trauma mata merupakan penyebab kebutaan tersering setelah katarak, glaukoma, kelainan refraksi, gangguan retina dan kelainan kornea. ${ }^{2}$

Trauma mata meliputi 55 juta kasus di seluruh dunia, dimana 1,6 juta kasus trauma mata mengalami kebutaan, 2,3 juta kasus trauma mata mengalami penurunan visus bilateral, dan 19 juta kasus trauma mata mengalami penurunan visus unilateral setiap tahunnya. Trauma mata di Amerika Serikat meliputi 2,4 juta kasus setiap tahunnya dan seperlima di antaranya mengalami kebutaan. ${ }^{3}$ Prevalensi trauma mata di India meliputi $2,4 \%$, dimana $11,4 \%$ dari prevalensi tersebut mengalami kebutaan. ${ }^{4}$ Trauma mata termasuk permasalahan kesehatan yang sering terjadi di Asia Tenggara. ${ }^{5}$ Setiap 1 dari 20 orang di Singapura mengalami trauma mata. ${ }^{6}$

Berdasarkan jenis trauma mata, hasil penelitian di Rumah Sakit Adam Malik dan di IGD RSUP Dr.M.Djamil Padang menunjukkan bahwa trauma mata yang tersering adalah trauma tumpul.Penelitian di Rumah Sakit Adam Malik pada tahun 2015 memperoleh 141 kasus trauma mata dengan trauma mata tumpul sebanyak 92 kasus $(65,3 \%){ }^{7}$ Penelitian di Instalasi Gawat Darurat RSUP Dr.M.Djamil Padang pada tahun 2014 memperoleh 224 kasus trauma mata dengan trauma mata tumpul sebanyak 91 kasus $(40,6 \%)^{8}$

Berdasarkan lingkungan pekerjaan, trauma mata lebih sering terjadi pada pekerja outdoor (buruh, petani, nelayan, dan lain-lain) dibandingkan pekerja indoor (ibu rumah tangga, guru, pelajar dan lain-lain), karena pekerja outdoor lebih banyak beraktivitas diluar ruangan serta lebih beresiko terkena cedera.Trauma mata menempati urutan ketiga kecelakaan kerja terbanyak pada seluruh pekerja industri di kawasan Pulo Gadung Jakarta dan merupakan kecelakaan kerja tersering pada pekerja dibagian industri baja. ${ }^{9}$

Berdasarkan jenis kelamin, trauma mata lebih sering terjadi pada laki-laki dibandingkan perempuan. ${ }^{7}$ Penelitian di Rumah Sakit Matini Kashan pada tahun 2013 mendapatkan 69 (73,4\%) kasus trauma mata pada laki-laki dan $25(26,6 \%)$ kasus pada perempuan. ${ }^{10}$ Penelitian di Rumah Sakit Sanglah Denpasar pada tahun 2017 mendapatkan 671 (74,10\%) kasus trauma mata pada laki-laki dan 234 (25,90\%) kasus pada perempuan. ${ }^{11}$

Berdasarkan usia, trauma mata paling sering terjadi pada usia dewasa muda. ${ }^{10}$ Sebagian besar di usia tersebut sudah memiliki pekerjaan dan memiliki banyak kegiatan di luar rumah. ${ }^{9}$ Penelitian di Rumah Sakit Dr.B.R Ambedkar tahun 2015 mendapatkan 100 kasus trauma mata dengan 57 (57\%) kasus pada usia 22-30 tahun. ${ }^{3}$ Penelitian di RSUP Sanglah Denpasar tahun 2010 mendapatkan 926 kasus trauma mata dengan $567(61,2 \%)$ kasus pada usia 15-40 tahun. ${ }^{12}$

Berdasarkan lateralisasi trauma, trauma mata unilateral lebih sering terjadi dibandingkan trauma mata bilateral. ${ }^{10}$ Penelitian di Rumah Sakit Bemina Srinagar tahun 2014 mendapatkan 17 kasus trauma mata unilateral dan 3 kasus trauma mata bilateral. ${ }^{13}$ Penelitian di Rumah Sakit H. Adam Malik tahun 2015 mendapatkan $77,2 \%$ kasus trauma mata unilateral dan $22,8 \%$ trauma mata bilateral. $^{7}$

Trauma mata dapat menimbulkan lesi pada mata. Sekecil apapun lesi tersebut tetap menimbulkan rasa sakit dan tidak nyaman karena mata merupakan salah satu jaringan tubuh yang sangat sensitif.Trauma mata menimbulkan banyak kerugian, mulai dari segi fisik, psikologi, hingga sosioekonomi. Penelitian di RSUP Sanglah Denpasar tahun 2010 mendapatkan 134 kasus penurunan visus dan 119 kasus kebutaan akibat trauma mata. ${ }^{12}$ Mereka yang mengalami kebutaan akibat trauma mata akan kehilangan pekerjaan, kehilangan penghasilan, perubahan gaya hidup, perubahan perilaku sosial, tidak percaya diri dan depresi.

Sebagian besar penatalaksanaan trauma mata membutuhkan biaya yang cukup besar. Kebutaan akibat trauma mata sebenarnya dapat dicegah jika di 
lakukan penanganan dengan segera. ${ }^{12} 80-85 \%$ trauma disebabkan oleh kelalaian dan kesalahan saat bekerja, misalnya tidak memakai alat pelindung diri (APD) selama bekerja. ${ }^{9}$ Informasi mengenai karakteristik dan epidemiologi trauma mata di Indonesia dan di Sumatera Barat masih sangat sedikit, sehingga banyak masyarakat yang tidak tahu akan bahaya dan dampak yang ditimbulkan akibat trauma mata tersebut. ${ }^{8}$

Sebagian besar kasus trauma mata tidak dapat diselesaikan di pelayanan kesehatan tingkat primer dan harus segera di rujuk ke pusat pelayanan yang lebih lengkap, yaitu ke pelayanan kesehatan tingkat tersier, seperti RSUP Dr M Djamil yang berada di kota Padang. ${ }^{8}$ Berdasarkan latar belakang yang telah diuraikan, perlu dilakukan penelitian mengenai analisis karakteristik pasien trauma mata di RSUP Dr.M.Djamil Padang tahun 2016.

\section{METODE}

Jenis penelitian ini adalah analitik dengan rancangan cross sectional untuk memperoleh hubungan antara variabel yang diteliti. Variabel independent nya yaitu jenis kelamin, usia, pekerjaan, lateralisasi, visus. Variabel dependent yaitu jenis trauma mata. Penelitian dilakukan di bagian rekam medis RSUP Dr.M.Djamil Padang mulai bulan Oktober 2017 sampai Februari 2018.

Populasi penelitian ini adalah seluruh pasien trauma mata yang datang ke IGD dan Poliklinik Mata RSUP Dr.M.Djamil Padang tahun 2016.

Sampel penelitian ini adalah seluruh populasi pasien trauma mata yang datang ke IGD dan Poliklinik Mata RSUP Dr M Djamil Padang tahun 2016 yang memenuhi kriteria inklusi dan tidak memiliki kriteria eksklusi. Kriteria inklusi subjek: rekam medis pasien trauma mata dengan datang yang lengkap (diagnosis, jenis kelamin, usia, pekerjaan, lateralisasi, dan visus). Kriteria eksklusi subjek: rekam medis yang hilang dan rekam medis yang tidak boleh diteliti karena masalah hukum, permintaan pasien atau keluarga pasien. Data diperoleh dari rekam medis pasien trauma mata di IGD dan Poliklinik Mata RSUP Dr.M.Djamil tahun 2016.

Data dianalisis secara statistik berdasarkan variabel yang dinilai menggunakan sistem komputerisasi yaitu analisis univariat dan bivariat.
Analisis univariat dilakukan untuk melihat distribusi frekuensi dari masing-masing variabel independent dan variabel dependent. Analisis bivariat dilakukan untuk menganalisis hubungan antara variabel independent dan variabel dependent. Hubungan dua variabel tersebut dianalisis dengan menggunakan uji Korelasi Lambda dan dikatakan bermakna bila $r>0.01$.

\section{HASIL}

Berdasarkan hasil penelitian ini,terdapat 76 pasien trauma mata di IGD dan Poliklinik Mata RSUP Dr M Djamil Padang tahun 2016yang memenuhi kriteria inklusi dengan karakteristik sebagai berikut.

Tabel 1. Distribusi frekuensi angka kejadian, jenis kelamin, usia, pekerjaan, lateralisasi, visus

\begin{tabular}{|c|c|c|c|}
\hline No & Variabel & $f$ & $\%$ \\
\hline \multirow[t]{3}{*}{1} & Jenis Kelamin & & \\
\hline & Laki-Laki & 59 & 77,6 \\
\hline & Perempuan & 17 & 22,4 \\
\hline \multirow[t]{5}{*}{2} & Usia & & \\
\hline & $0-11$ th & 20 & 26,3 \\
\hline & $12-21$ th & 18 & 23,7 \\
\hline & $22-45$ th & 21 & 27,6 \\
\hline & $>45$ th & 17 & 22,4 \\
\hline \multirow[t]{9}{*}{3} & Pekerjaan & & \\
\hline & Tidak bekerja & 6 & 7,9 \\
\hline & Pelajar & 34 & 44,7 \\
\hline & IRT & 6 & 7,9 \\
\hline & Wiraswasta & 11 & 14,5 \\
\hline & Kuli bangunan & 9 & 11,8 \\
\hline & Petani & 5 & 6,6 \\
\hline & Sopir & 4 & 5,3 \\
\hline & Nelayan & 1 & 1,3 \\
\hline \multirow[t]{3}{*}{4} & Lateralisasi & & \\
\hline & Unilateral & 72 & 94,7 \\
\hline & Bilateral & 4 & 5,3 \\
\hline \multirow[t]{3}{*}{5} & Visus & & \\
\hline & $<6 / 6-3 / 60$ & 27 & 48,5 \\
\hline & $<3 / 60$ & 49 & 51,5 \\
\hline
\end{tabular}

Berdasarkan Tabel 1, trauma mata paling sering terjadi pada pasien dengan jenis kelamin lakilaki, pasien berusia 22-45 tahun, serta pasien dengan profesi pelajar.Trauma mata paling sering mengenai satu mata, dan paling sering mengakibatkan kebutaan. Diagnosis trauma mata yang paling sering ditemukan 
yaitu ruptur kornea dan jenis trauma mata yang paling banyak ditemukan pada penelitian ini yaitu trauma tajam.

Tabel 2. Diagnosis dan jenis trauma pasien trauma mata

\begin{tabular}{|c|c|c|c|}
\hline No. & Variabel & $f$ & $\%$ \\
\hline \multirow[t]{17}{*}{1} & Diagnosis & & \\
\hline & Hematom Palpebra & 2 & 2,63 \\
\hline & Corpus Alienum Konjungtiva & 1 & 1,32 \\
\hline & Erosi Kornea & 5 & 6,58 \\
\hline & Perdarahan Subkonjungtiva & 3 & 3,95 \\
\hline & Hifema & 5 & 6,58 \\
\hline & Subluksasi Lensa & 1 & 1,32 \\
\hline & Glaukoma Sekunder & 3 & 3,95 \\
\hline & Ablasio Retina & 2 & 2,63 \\
\hline & Commotio Retina & 3 & 3,95 \\
\hline & TON & 2 & 2,63 \\
\hline & Ruptur Palpebra & 15 & 19,74 \\
\hline & Laserasi Konjungtiva & 4 & 5,26 \\
\hline & Ruptur Kornea & 16 & 21,05 \\
\hline & Ruptur Sklera & 1 & 1,32 \\
\hline & Ruptur Korneosklera & 10 & 13,16 \\
\hline & Trauma Kimia & 3 & 3,95 \\
\hline \multirow[t]{4}{*}{2} & Jenis Trauma Mata & & \\
\hline & Trauma Tumpul & 27 & 35,5 \\
\hline & Trauma Tajam & 46 & 60,5 \\
\hline & Trauma Kimia & 3 & 4 \\
\hline
\end{tabular}

Berdasarkan Tabel 3, jenis trauma mata yang didapatkan dari penelitian ini adalah trauma tumpul, trauma tajam, dan trauma kimia. Semua jenis trauma tersebut lebih sering terjadi pada laki-laki dan trauma tajam memiliki persentase tertinggi pada laki-laki (57,6\%) maupun perempuan $(70,6 \%)$.

Tabel 3. Hubungan jenis kelamin dengan jenis trauma mata

\begin{tabular}{|c|c|c|c|c|}
\hline \multirow[b]{2}{*}{ Variabel } & \multicolumn{3}{|c|}{ Jenis Trauma Mata } & \multirow[b]{2}{*}{$r$} \\
\hline & $\begin{array}{c}\text { Trauma } \\
\text { Tumpul } \\
\text { n (\%) }\end{array}$ & $\begin{array}{c}\text { Trauma } \\
\text { Tajam } \\
\text { n (\%) }\end{array}$ & $\begin{array}{c}\text { Trauma } \\
\text { Kimia } \\
\text { n (\%) }\end{array}$ & \\
\hline \multicolumn{5}{|l|}{ Jenis kelamin } \\
\hline Laki-Laki & $\begin{array}{c}22 \\
(37,3 \%)\end{array}$ & $\begin{array}{c}34 \\
(57,6 \%)\end{array}$ & $3(5,1 \%)$ & \multirow[t]{2}{*}{0,00} \\
\hline Perempuan & $\begin{array}{c}5 \\
(29,4 \%)\end{array}$ & $\begin{array}{c}12 \\
(70,6 \%)\end{array}$ & 0 & \\
\hline Total & 27 & 46 & 3 & \\
\hline
\end{tabular}

Seluruh pasien trauma kimia pada penelitian ini berjenis kelamin laki-laki. Hasil uji korelasi Lambda menunjukkan nilai $r=0,000$ yang berarti tidak terdapat hubungan antara jenis kelamin dengan jenis trauma mata.

Tabel 4. Hubungan usia dengan jenis trauma mata

\begin{tabular}{|c|c|c|c|c|}
\hline \multirow[b]{2}{*}{ Variabel } & \multicolumn{3}{|c|}{ Jenis Trauma Mata } & \multirow[b]{2}{*}{$r$} \\
\hline & $\begin{array}{c}\text { Trauma } \\
\text { Tumpul } \\
\text { n (\%) }\end{array}$ & $\begin{array}{c}\text { Trauma } \\
\text { Tajam } \\
\text { n (\%) }\end{array}$ & $\begin{array}{c}\text { Trauma } \\
\text { Kimia } \\
\text { n (\%) }\end{array}$ & \\
\hline Usia & & & & \\
\hline $0-11$ th & $\begin{array}{c}7 \\
(35 \%)\end{array}$ & $\begin{array}{c}13 \\
(65 \%)\end{array}$ & 0 & \\
\hline $12-21$ th & $\begin{array}{c}11 \\
(61,1 \%)\end{array}$ & $\begin{array}{c}7 \\
(38,9 \%)\end{array}$ & 0 & 0,109 \\
\hline $22-45$ th & $\begin{array}{c}7 \\
(33,4 \%)\end{array}$ & $\begin{array}{c}12 \\
(57,1 \%)\end{array}$ & $2(9,5 \%)$ & \\
\hline$>45$ th & $\begin{array}{c}2 \\
(11,8 \%)\end{array}$ & $\begin{array}{c}14 \\
(82,3 \%)\end{array}$ & $1(5,9 \%)$ & \\
\hline ota & 27 & 46 & 3 & \\
\hline
\end{tabular}

Berdasarkan Tabel 4, pasien berusia 12-21 tahun lebih sering mengalami trauma tumpul, sedangkan pasien berusia 0-11 tahun, 22-45 tahun, dan diatas 45 tahun lebih sering mengalami trauma tajam. Trauma tajam memiliki persentase tertinggi pada pasien berusia diatas 45 tahun (82,3\%). Seluruh pasien trauma kimia pada penelitian ini berusia diatas 22 tahun, dimana trauma kimia memiliki persentase tertinggi pada pasien berusia 22-45 tahun. Hasil uji korelasi Lambda menunjukkan nilai $r$ 0,109 yang berarti terdapat hubungan antara usia dengan jenis trauma mata.

Berdasarkan Tabel 5, pasien dengan profesi pelajar lebih sering mengalami trauma tumpul dan trauma tajam. Pasien dengan profesi ibu rumah tangga, wiraswasta, kuli bangunan, petani, sopir, nelayan, serta yang tidak bekerja (bayi dan balita) lebih sering mengalami trauma tajam. Trauma kimia terjadi pada pasien dengan profesi pelajar dan kuli bangunan, dimana trauma kimia memiliki persentase tertinggi pada profesi kuli bangunan. Hasil uji korelasi Lambda menunjukkan nilai $r=0,024$ yang berarti terdapat hubungan antara pekerjaan dengan jenis trauma mata. 
Tabel 5. Hubungan pekerjaan dengan jenis trauma mata

\begin{tabular}{|c|c|c|c|c|}
\hline \multirow[b]{2}{*}{ Variabel } & \multicolumn{3}{|c|}{ Jenis Trauma Mata } & \multirow[b]{2}{*}{$r$} \\
\hline & $\begin{array}{c}\text { Trauma } \\
\text { Tumpul } \\
\text { n (\%) }\end{array}$ & $\begin{array}{c}\text { Trauma } \\
\text { Tajam } \\
\text { n (\%) }\end{array}$ & $\begin{array}{c}\text { Trauma } \\
\text { Kimia } \\
\text { n (\%) }\end{array}$ & \\
\hline Pekerjaan & & & & \\
\hline Tidak Bekerja & $\begin{array}{c}2 \\
(33,3 \%)\end{array}$ & $\begin{array}{c}4 \\
(66,7 \%)\end{array}$ & 0 & \\
\hline Pelajar & $\begin{array}{c}17 \\
(50 \%)\end{array}$ & $\begin{array}{c}16 \\
(47,1 \%)\end{array}$ & $1(2,9 \%)$ & \\
\hline IRT & $\begin{array}{c}1 \\
(16,7 \%)\end{array}$ & $\begin{array}{c}5 \\
(83,3 \%)\end{array}$ & 0 & \\
\hline Wiraswasta & $\begin{array}{c}5 \\
(45,5 \%)\end{array}$ & $\begin{array}{c}6 \\
(54,5 \%)\end{array}$ & 0 & 0,024 \\
\hline Kuli Bangunan & $\begin{array}{c}1 \\
(11,1 \%)\end{array}$ & $\begin{array}{c}6 \\
(66,7 \%)\end{array}$ & $\begin{array}{c}2 \\
(22,2 \%)\end{array}$ & \\
\hline Petani & $\begin{array}{c}1 \\
(20 \%)\end{array}$ & $\begin{array}{c}4 \\
(80 \%)\end{array}$ & 0 & \\
\hline Sopir & 0 & $\begin{array}{c}4 \\
(100 \%)\end{array}$ & 0 & \\
\hline Nelayan & 0 & $\begin{array}{c}1 \\
(100 \%)\end{array}$ & 0 & \\
\hline Total & 27 & 46 & 3 & \\
\hline
\end{tabular}

Tabel 6. Hubungan lateralisasi dengan jenis trauma mata

\begin{tabular}{|c|c|c|c|c|}
\hline \multirow[b]{2}{*}{ Variabel } & \multicolumn{3}{|c|}{ Jenis Trauma Mata } & \multirow[b]{2}{*}{$r$} \\
\hline & $\begin{array}{c}\text { Trauma } \\
\text { Tumpul } \\
\text { n (\%) }\end{array}$ & $\begin{array}{c}\text { Trauma } \\
\text { Tajam } \\
\text { n (\%) }\end{array}$ & $\begin{array}{c}\text { Trauma } \\
\text { Kimia } \\
\text { n (\%) }\end{array}$ & \\
\hline \multicolumn{5}{|l|}{ Lateralisasi } \\
\hline Unilateral & $\begin{array}{c}24 \\
(33,3 \%)\end{array}$ & $\begin{array}{c}42 \\
(62,5 \%)\end{array}$ & $3(4,2 \%)$ & \multirow[t]{2}{*}{0,026} \\
\hline Bilateral & $\begin{array}{c}3 \\
(75 \%)\end{array}$ & $\begin{array}{c}1 \\
(25 \%)\end{array}$ & 0 & \\
\hline Total & 27 & 46 & 3 & \\
\hline
\end{tabular}

Berdasarkan Tabel 6, semua jenis trauma mata pada penelitian ini lebih sering mengenai satu mata, dimana trauma tajam memiliki persentase unilateral yang tertinggi (62,5\%). Trauma yang mengenai kedua mata lebih sering disebabkan oleh trauma tumpul $(75 \%)$. Seluruh pasien trauma kimia pada penelitian ini mengenai satu mata. Hasil uji korelasi Lambda menunjukkan nilai $r=0,026$ yang berarti terdapat hubungan antara lateralisasi trauma dengan jenis trauma mata.
Tabel 7. Hubungan visus dengan jenis trauma mata

\begin{tabular}{|c|c|c|c|c|}
\hline \multirow[b]{2}{*}{ Variabel } & \multicolumn{3}{|c|}{ Jenis Trauma Mata } & \multirow[b]{2}{*}{$r$} \\
\hline & $\begin{array}{c}\text { Trauma } \\
\text { Tumpul } \\
\text { n (\%) }\end{array}$ & $\begin{array}{c}\text { Trauma } \\
\text { Tajam } \\
\text { n (\%) }\end{array}$ & $\begin{array}{c}\text { Trauma } \\
\text { Kimia } \\
\text { n (\%) }\end{array}$ & \\
\hline Visus & & & & \\
\hline$<6 / 6-3 / 60$ & $\begin{array}{c}10 \\
(37,04 \%)\end{array}$ & $\begin{array}{c}17 \\
(62,96 \%)\end{array}$ & 0 & 0,00 \\
\hline$<3 / 60$ & $\begin{array}{c}16 \\
(32,7 \%)\end{array}$ & $\begin{array}{c}33 \\
(67,3 \%)\end{array}$ & 0 & \\
\hline Total & 27 & 46 & 3 & \\
\hline
\end{tabular}

Berdasarkan Tabel 7, trauma tajam paling sering menyebabkan penurunan visus $(62,96 \%)$ dan kebutaan $(67,3 \%)$. Seluruh pasien trauma kimia pada penelitian ini memiliki visus normal. Hasil uji korelasi Lambda menunjukkan nilai $r=0,000$ yang berarti tidak terdapat hubungan antara visus pasien dengan jenis trauma mata.

\section{PEMBAHASAN}

\section{Hubungan Jenis Kelamin dengan Jenis Trauma Mata}

Hasil uji statistik menunjukkan nilai $r=0,000$ yang berarti tidak terdapat hubungan antara jenis kelamin dengan jenis trauma mata. Hasil uji statistik tersebut sesuai dengan Vats et al (2008), dimana trauma mata lebih dikaitkan dengan pekerjaan, bukan jenis kelamin. ${ }^{4}$ Berdasarkan hasil penelitian ini, persentase trauma mata yang berjenis kelamin laki-laki $(77,6 \%)$ lebih tinggi dibandingkan perempuan $(22,4 \%)$. Sesuai dengan penelitian Vats et al (2008), bahwa lakilaki 4 kali lebih sering mengalami trauma mata dibandingkan perempuan. ${ }^{4}$ Semua penelitian trauma mata menunjukkan hasil yang sama dengan hasil penelitian ini, bahwa laki-laki lebih sering mengalami trauma mata dibandingkan perempuan. Hal ini dikarenakan laki-laki lebih banyak terlibat aktivitas diluar ruangan, kurang memperhatikan keselamatan diri saat bekerja, dan lebih beresiko terkena cedera dibandingkan perempuan. ${ }^{11}$

Seluruh jenis trauma mata yang ditemukan pada penelitian ini (trauma tumpul, trauma tajam, dan trauma kimia) lebih sering terjadi pada laki-laki dibandingkan perempuan. Sesuai dengan penelitian Djelantik et al (2010), bahwa seluruh jenis trauma mata yang diteliti 
lebih sering terjadi pada laki-laki dibandingkan perempuan. $^{12}$

Laki-laki dan perempuan lebih sering mengalami trauma tajam dibandingkan trauma tumpul dan trauma kimia. Sesuai dengan penelitian Phogatet al (2012) bahwa laki-laki dan perempuan lebih sering mengalami trauma tajam. ${ }^{14} \mathrm{Hal}$ tersebut dikaitkan dengan etiologinya yang berbeda, dimana laki-laki lebih sering terkena cedera saat bekerja, misalnya tertusuk besi, paku, potongan kayu, potongan kaca, duri sawit dan lain-lain, sedangkan perempuan lebih sering kontak dengan peralatan rumah tangga seperti pisau, gelas, piring, garpu, sendok dan lain-lain. ${ }^{9}$

Seluruh pasien trauma kimia berjenis kelamin laki-laki, pada penelitian ini tidak ditemukan pasien trauma kimia berjenis kelamin perempuan. Sesuai dengan penelitian Singh et al (2013) bahwa trauma kimia lebih sering terjadi pada laki-laki dibandingkan perempuan. Hal tersebut lebih dikaitkan dengan pekerjaan, dimana pada penelitian ini sebagian besar pasien trauma kimia berprofesi sebagai kuli bangunan, biasanya profesi tersebut dilakukan oleh laki-laki. Profesi kuli bangunan lebih sering kontak dengan bahan-bahan kimia saat bekerja, seperti serbuk semen, cat tembok, air aki, oli dan lain-lain. Trauma kimia pada perempuan lebih dikaitkan dengan peralatan rumah tangga, dimana perempuan lebih sering kontak dengan minyak goreng, cairan pencuci piring, cairan pembersih lantai, cat kuku dan lain-lain. ${ }^{15}$

\section{Hubungan Usia dengan Jenis Trauma Mata}

Hasil uji statistik menunjukkan nilai $r=0,109$ yang berarti terdapat hubungan antara usia dengan jenis trauma mata. Hasil uji statistik tersebut sesuai dengan Sujatha et al (2015), dimana trauma mata memiliki persentase tertinggi pada usia produktif. Berdasarkan hasil penelitian ini, trauma mata lebih sering terjadi pada pasien berusia 22-45 tahun. Usia tersebut dikategorikan sebagai usia dewasa muda. Sesuai dengan penelitian Sujatha et al (2015) bahwa trauma mata paling sering terjadi pada pasien berusia 22-30 tahun. ${ }^{3}$ Hal ini dikarenakan sebagian besar pada usia tersebut sudah memiliki pekerjaan dan memiliki banyak kegiatan diluar rumah sehingga lebih beresiko terkena cedera. $^{9}$
Trauma mata juga sering ditemukan pada usia anak-anak (0-11 tahun). Berdasarkan penelitian ini, persentase pasien trauma mata berusia 0-11 tahun hampir sama dengan persentase pasien trauma mata berusia 22-45 tahun. Sesuai dengan penelitian Abbott (2013) yang menjelaskan bahwa anak-anak sering mengalami trauma mata, dimana $25 \%$ dari 1 juta anakanak didunia mengalami trauma mata setiap tahunnya. $\mathrm{Hal}$ ini dikarenakan anak-anak lebih aktif saat bermain, kurang memperhatikan keselamatan diri saat beraktivitas serta kurangnya pengawasan terhadap mereka. $^{16}$

Pasien berusia 0-11 tahun, 22-45 tahun, dan diatas 45 tahun lebih sering mengalami trauma tajam, diantara ketiga kategori usia tersebut, pasien berusia diatas 45 tahun memiliki persentase trauma tajam tertinggi (82,3\%). Sesuai dengan penelitian Patel (2015) bahwa trauma tajam paling sering terjadi pada pasien berusia diatas 60 tahun. Usia tersebut dikategorikan sebagai usia lanjut. Hal tersebut dikarenakan pada usia lanjut sering mengalami penyakit degeneratif seperti osteoporosis dan osteoarthritis yang menyebabkan pasien mudah terjatuh dan cedera saat berjalan. ${ }^{17}$

Pasien berusia 12-21 tahun lebih sering mengalami trauma tumpul. Sesuai dengan penelitian Djelantik et al (2010) bahwa trauma tumpul paling sering terjadi pada usia 14-40 tahun. Hal ini dikarenakan sebagian besar pada usia tersebut sudah memiliki pekerjaan dan lebih beresiko terkena cedera saat bekerja, seperti tertinju, terpukul, terkena lemparan getah karet, batu, tanah liat dan lain-lain. ${ }^{12}$

Seluruh pasien trauma kimia berusia diatas 22 tahun, dimana pasien berusia 22-45 tahun memiliki persentase trauma kimia tertinggi. Sesuai dengan penelitian Singh et al (2013) bahwa trauma kimia lebih sering terjadi pada pasien berusia diatas 30 tahun. Hal tersebut lebih dikaitkan dengan pekerjaan, pada penelitian ini sebagian besar pasien trauma kimia berprofesi sebagai kuli bangunan. Profesi tersebut biasanya dilakukan oleh orang dewasa, serta lebih sering kontak dengan bahan-bahan kimia saat bekerja, seperti serbuk semen, cat tembok, air aki, oli, dan lainlain. $^{15}$ 


\section{Hubungan Pekerjaan dengan Jenis Trauma Mata}

Hasil uji statistik menunjukkan nilai $r=0,024$ yang berarti terdapat hubungan antara pekerjaan dengan jenis trauma mata. Hasil uji statistik tersebut sesuai denganTabatabaei et al (2013), bahwa trauma mata dipengaruhi oleh pekerjaan, dimana trauma mata lebih sering terjadi pada pekerja outdoor dibandingkan pekerja indoor. ${ }^{18}$ Berdasarkan hasil penelitian ini, trauma mata paling sering terjadi pada pelajar. Sesuai dengan hasil penelitian Samalo (2016), bahwa trauma mata paling sering terjadi pada pelajar. ${ }^{8} \mathrm{Hal}$ tersebut dikarenakan pelajar yang cenderung aktif saat bermain atau beraktivitas lainnya, serta kurangnya pengawasan terhadap mereka. Perkelahian yang sering terjadi pada pelajar, seperti tertinju, terpukul, terbentur, terjatuh dan lain-lain mengakibatkan tingginya persentase trauma mata pada pelajar. ${ }^{16}$

Pelajar sering mengalami trauma tumpul dan trauma tajam. Hal tersebut dikaitkan dengan peralatan belajar dan peralatan bermain, dimana trauma tumpul terjadi karena pelajar sering kontak dengan kotak pensil, botol minum, bola, boneka, plastisin dan lainlain, sedangkan trauma tajam terjadi karena pelajar sering kontak dengan pena, pensil, peraut pensil dan lain-lain. ${ }^{16}$

Pasien dengan profesi ibu rumah tangga, wiraswasta, kuli bangunan, petani, sopir, nelayan, serta yang tidak bekerja (bayi dan balita) paling sering mengalami trauma tajam. Hal tersebut dikaitkan dengan etiologi masing-masing profesi yang berbeda, dimana ibu rumah tangga sering kontak dengan peralatan rumah tangga (pisau, gelas, piring, garpu sendok), wiraswasta, kuli bangunan, petani, sopir dan nelayan sering kontak dengan peralatan kerja (tertusuk besi, paku, potongan kayu, potongan kaca, duri sawit, dan lain-lain), sedangkan yang tidak bekerja, seperti bayi dan balita cenderung aktif saat bermain, kurang memperhatikan keselamatan diri saat beraktivitas serta kurangnya pengawasan terhadap mereka. ${ }^{9,14,16}$

Trauma kimia ditemukan pada pasien dengan profesi pelajar dan kuli bangunan, dimana profesi kuli bangunan memiliki persentase trauma kimia tertinggi. Hal tersebut dikaitkan dengan peralatan dan bahan kerja yang digunakan, dimana pada profesi kuli bangunan lebih sering kontak dengan bahan-bahan kimia seperti serbuk semen, cat tembok, air aki, oli dan lain-lain. ${ }^{15}$ Trauma kimia pada pelajar lebih dikaitkan dengan peralatan belajar seperti tinta pena, tinta spidol, dan lain-lain, serta peralatan bermain seperti cairan peniup gelembung balon, cat untuk menggambar, dan lain-lain. $^{16}$

\section{Hubungan Lateralisasi dengan Jenis Trauma Mata}

Hasil uji statistik menunjukkan nilai $r=0,026$ yang berarti terdapat hubungan antara lateralisasi trauma dengan jenis trauma mata. Hasil uji statistik tersebut sesuai dengan Aghadoost et al, dimana trauma mata paling sering mengenai satu mata dibandingkan kedua mata. ${ }^{10}$ Berdasarkan hasil penelitian ini, trauma mata lebih sering mengenai satu mata $(94,7 \%)$. Semua penelitian trauma mata menunjukkan hasil yang sama dengan hasil penelitian ini, seperti penelitian Rashid et al (2014) bahwa trauma mata lebih sering mengenai satu mata dibandingkan kedua mata. ${ }^{13}$ Tingginya persentase trauma mata unilateral menjadi alasan utama trauma mata sebagai penyebab terbanyak dari kebutaan unilateral. ${ }^{12}$

Semua jenis trauma mata pada penelitian ini paling sering mengenai satu mata, dimana trauma tajam memiliki persentase unilateral tertinggi $(62,5 \%)$. Sesuai dengan penelitian Ajayi et al (2014) bahwa trauma tajam paling sering mengenai satu mata. Hal tersebut dikaitkan dengan bentuk dan ukuran benda yang mengenai mata, dimana benda tajam memiliki ujung yang runcing dan berukuran kecil sehingga cenderung mengenai satu mata. ${ }^{19}$

Trauma yang mengenai kedua mata lebih sering disebabkan oleh trauma tumpul (75\%). Hasil penelitian tersebut sesuai dengan hasil penelitian Pradana et al (2017), bahwa trauma tumpul lebih sering mengenai kedua mata. ${ }^{11}$ Sama seperti trauma tajam, trauma tumpul juga dikaitkan dengan bentuk dan ukuran benda yang mengenai mata, dimana benda tumpul memiliki ujung yang tumpul dan berukuran lebih besar dibandingkan benda tajam sehingga cenderung mengenai kedua mata. ${ }^{19}$

Seluruh pasien trauma kimia pada penelitian ini mengenai satu mata. Beberapa penelitian lain menunjukkan hasil yang bervariasi, seperti penelitian Aldy (2009) menjelaskan bahwa trauma kimia lebih sering mengenai satu mata, sedangkan penelitian Djelantik (2010) menjelaskan bahwa trauma kimia lebih 
sering mengenai kedua mata. ${ }^{12,20}$ Trauma kimia pada mata tergantung dari jumlah bahan kimia yang mengenai mata, semakin banyak jumlah bahan kimia tersebut, maka semakin besar kemungkinan mengenai kedua mata. ${ }^{15}$

\section{Hubungan Visus dengan Jenis Trauma Mata}

Hasil uji statistik menunjukkan nilai $r=0,000$ yang berarti tidak terdapat hubungan antara visus pasien dengan jenis trauma mata, akan tetapi hasil uji statistik tersebut tidak sesuai dengan Eva (2011) dan Omalese et al (2011)yang menjelaskan bahwa trauma mata dapat mempengaruhi visus pasien. ${ }^{21,22}$ Hasil dari penelitian ini sesuai dengan pendapat tersebut, dimana trauma tajam paling sering menyebabkan penurunan visus $(62,96 \%)$ dan kebutaan $(67,3 \%)$. Hasil penelitian tersebut juga sesuai dengan hasil penelitian lqbal et al (2014) bahwa trauma tajam paling sering menyebabkan penurunan visus dan kebutaan. ${ }^{23} \mathrm{Hal}$ ini dikarenakan trauma tajam langsung menembus bola mata sehingga merusak anatomi dan fisiologi mata. ${ }^{1}$

Seluruh pasien trauma kimia memiliki visus normal, pada penelitian ini tidak ditemukan pasien trauma kimia dengan penurunan visus atau kebutaan. Sesuai dengan penelitian Scott (2016) bahwa sebagian besar trauma kimia tidak mempengaruhi visus. ${ }^{24} \mathrm{Hal}$ tersebut tergantung dari cepat atau lambatnya respon seseorang jika bahan kimia mengenai mata. Semakin cepat di tatalaksana maka semakin kecil kemungkinan mengalami penurunan visus dan kebutaan. ${ }^{15}$ Trauma kimia juga dikaitkan dengan zat kimia, konsentrasi zat, dan lama kontak zat tersebut dengan mata. Bahan alkali lebih sering menyebabkan kerusakan jaringan mata yang progresif dan kebutaan jika dibandingkan dengan bahan asam. Semakin tinggi konsentrasi zat kimia dan semakin lama kontak zat tersebut dengan mata, maka semakin beresiko menimbulkan kerusakan jaringan mata dan kebutaan. ${ }^{1}$

\section{SIMPULAN}

Terdapat hubungan antara usia, pekerjaan, lateralisasi dan visus pasien trauma mata terhadap jenis trauma mata.

Tidak terdapat hubungan antara jenis kelamin pasien trauma mata terhadap jenis trauma mata.

\section{DAFTAR PUSTAKA}

1. Ilyas S, Yulianti SR. Ilmu penyakit mata. Edisi ke-5. Jakarta: Badan Penerbit FKUI; 2015.

2. Bourne RRA, Stevens GA, White RA, Smith JL, Flaxman SR, Price $\mathrm{H}$, et al. Causes vision loss worldwide, 1990-2010: a systematic analysis. The Lancet Global Health. 2013;1(6):339-49.

3. Sujatha MAR, Nazlin A, Prakash S, Nousheen S. Prevalence of visual impairment after blunt ocular trauma in a tertiary hospital. Int $\mathrm{J}$ of Sci Stud. 2015;3(4):36-9.

4. Vats S, Murthy GV, Chandra M, Gupta SK, Vashist P, Gogoi M. Epidemiological study of ocular trauma in an urban slum population in Delhi, India.Indian $\mathrm{J}$ of Ophthalmol. 2008;56(4):313-16.

5. Dhillon PK, Jeemon $P$, Arora NK, Mathur $P$, Maskey M, Sukirna RD, et al. Status of epidemiology in the WHO South-East Asia Region: burden of disease, determinants of health and epidemiological research, workforce and training capacity. Int J of Epid. 2013;42(1):361.

6. Chua D, Wong W, Lamoureux EL, Aung T, Saw SM, Wong TY. The prevalence and risk factors of ocular trauma: the Singapore Indian eye study. J Ophthalmol Epid. 2011;18(6):281-87.

7. Lubis RR, Wulandari $C$. The characteristic of ocular trauma in adulthood patients at Adam Malik Hospital period 2011-2012. Int $\mathrm{J}$ of PharmTech Res. 2015;8(2):200-3.

8. Samalo D. Gambaran pasien trauma mata di IGD RSUP Dr M Djamil Padang tahun 2014 (skripsi). Padang: Universitas Andalas; 2016.

9. Riyadina W. Kecelakaan kerja dan cedera yang dialami oleh pekerja industri di kawasan industri Pulo Gadung Jakarta. Makara Kesehatan. 2007;11(1):25-31.

10. Aghadoost D, Fazel MR, Aghadoost H, Aghadoost N. Pattern of ocular trauma among the elderly in Kashan, Iran. Chinese $\mathrm{J}$ of Traumatology. 2013;16(6):347-50.

11. Pradana PAS, Yuliawati $P$, Djelantik AAAS, Manuaba IBP, Triningrat AAMP, Utari NML.Karakteristik pasien trauma okuli di RSUP Sanglah Denpasar Bulan Juli 2011-Februari 2015. Med. 2017;48(3):174-80. 
12. Djelantik AS, Andayani A, Widiana IGR. The relation of onset of trauma and visual acuity on traumatic patient. JOI. 2010;7(3):85-90.

13. Rashid W, Shaheen N, Lone IA, Sajjad S. Pellet gun fire injuries in Kashmir Valley-cause of ocular morbidity. J Of Evol Med and Dent Sci. 2014;3(29):8051-8.

14. Phogat JK, Gagneja V, Sachdeva S, Rathi M. Evaluation of a case of penetrating ocular injury. Indian J of Clin Pract. 2012;22(12):28-30.

15. Singh P, Tyagi M, Kumar Y, Gupta K, Sharma P. Ocular chemical injuries and their management. Oman J of Ophthalmol. 2013;6(2):83-6.

16. Abbott J. The epidemiology and etiology of pediatric ocular trauma. Surv Ophthalmol. 2013;58(5):476-85.

17. Patel D. Eye injuries: improving our practice. Community Eye Health.2015;28(91):41-3.

18. Tabatabaei A, Kasaei A, Nikdel M, Shoar S, Esmaeili S, Mafi M, et al. Clinical characteristics and causality of eye lid laceration in Iran. Oman Med J. 2013;28(2):97-101.
19. Ajayi IA, Ajite KO, Omotoye OJ. Epidemiological survey of traumatic eye injury in a Southwestern Nigeria tertiary hospital. Pak $\mathrm{J}$ Ophthalmol. 2014;30(3):137-41.

20. Aldy F. Prevalensi kebutaan akibat trauma mata di Kabupaten Tapanuli Selatan (tesis). Medan: Universitas Sumatera Utara;2009.

21. Eva PR Jr ETC. Vaughan \& Asbury's general ophthalmol. Susanto D, penterjemah. Jakarta: Penerbit Buku Kedokteran EGC; 2011.

22. Omalese O, Omolade EO, Ogunloye OT, Omalase $\mathrm{BO}$, Ihenedu CO, Adosun AO. Pattern of ocular injuries in Owo Nigeria. $\mathrm{J}$ Ophthal Visual Res. 2011;6:114-8.

23. Iqbal $A$, Idrees $M$, Bashir $B$, Rehman $M$, Orakzai OK. Pattern of ocular trauma in District Swabi. J of Sheikh Zayed Med Colleg. 2014;5(4):696-701.

24. Scott R. The ocular trauma score. Community Eye Health J. 2016;28(91):44-5. 